University of Wollongong

Research Online

Faculty of Arts, Social Sciences and Humanities

- Papers

Faculty of Arts, Social Sciences \& Humanities

$1-1-2020$

Waitresses at sea: gender, race and service labour on ocean liners, c.1930s-1960s

Frances Steel

University of Wollongong, fsteel@uow.edu.au

Follow this and additional works at: https://ro.uow.edu.au/asshpapers

Research Online is the open access institutional repository for the University of Wollongong. For further information contact the UOW Library: research-pubs@uow.edu.au 


\title{
Waitresses at sea: gender, race and service labour on ocean liners, c.1930s-1960s
}

\begin{abstract}
(c) 2020, (c) 2020 Informa UK Limited, trading as Taylor \& Francis Group. Service labour on ships was feminised, but it was monopolised by men. Besides the limited role of the stewardess, women were not employed in general service positions until the 1930s when they began to be hired as waitresses in place of male dining-room stewards. This article considers the conditions of possibility for American and British lines recruiting white women in preference to men. This occurred at two significant junctures. Firstly, during the 1930s as race became more crucial to employment on American ships in transoceanic trades, and subsequently from the late 1950 s as shipping companies responded to the rise of commercial aviation. By examining the changing face of service employment at sea and the labels used to designate male and female service labour as both parallel and foil to practices on land and in flight, this article casts new interpretive light on the relationship between gender, identity, work and status.
\end{abstract}

\section{Publication Details}

Steel, F. (2020). Waitresses at sea: gender, race and service labour on ocean liners, c.1930s-1960s. Women's History Review, 


\title{
Waitresses at Sea: Gender, race and service labour on ocean liners, c.1930s-1960s
}

Frances Steel

School of Humanities and Social Inquiry, University of Wollongong, Wollongong, NSW 2522, Australia

fsteel@uow.edu.au

ORCiD - 0000-0001-7240-1530

\begin{abstract}
Service labour on ships was feminised, but it was monopolised by men. Besides the limited role of the stewardess, women were not employed in general service positions until the 1930s when they began to be hired as waitresses in place of male dining-room stewards. This article considers the conditions of possibility for American and British lines recruiting white women in preference to men. This occurred at two significant junctures. Firstly, during the 1930s as race became more crucial to employment on American ships in transoceanic trades, and subsequently from the late 1950s as shipping companies responded to the rise of commercial aviation. By examining the changing face of service employment at sea and the labels used to designate male and female service labour as both parallel and foil to practices on land and in flight, this article casts new interpretive light on the relationship between gender, identity, work and status.
\end{abstract}

Keywords

commercial aviation, passenger shipping, service employment, stewards, waitresses

Funding

Research for this article was supported by the Australian Research Council (project DE120101731). 
In 1956 the American Matson Line's new passenger liner, the Mariposa, made its maiden voyage from San Francisco to Sydney, resuming a transpacific service between the United States and Australia suspended since the outbreak of World War II. A crewing innovation on the ship announced a new era of mass commercial travel in the Pacific. This was the employment of thirty waitresses in the place of male dining-room stewards. The women attracted substantial press coverage and were soon lauded as 'celebrities'. ${ }^{1}$ Despite the attention they received the Mariposa waitresses were not the first to enter American ships' dining rooms. This breach began to occur in the early 1930s. With service work only beginning to attract sustained historical attention, however, sea-going waitresses are hard to find in maritime, labour, or women's history. Examining their employment and contemporary attitudes towards it requires bringing shipping into dialogue with labour practices on shore and in flight. This article, in attending to the mutual fashioning of hospitality service employment across land, sea, and air, aims to open up new interpretive space for the figure of the waitress.

Men long-dominated service work on ships. Nineteenth-century British migrant ships first employed women in small numbers as stewardesses (a distinct group of service workers) to deal with the intimate concerns of female emigrants. By 1900 stewardesses were a permanent fixture as intensified competition forced shipping companies to hire women to serve female cabin passengers. ${ }^{2}$ Employed in a supplementary role and not generally at the expense of male workers, stewardesses have received the lion's share of historical attention, both in the literature on women's employment at sea and shipboard service cultures more

\footnotetext{
${ }^{1}$ Honolulu Advertiser, 3 March 1957, 99.

${ }^{2}$ Sari Mäenpää, 'Comfort and Guidance for Female Passengers: The origins of women's employment on British Passenger Liners 1850-1914', Journal for Maritime Research 6, no. 1 (2004): 145-164.
} 
generally. ${ }^{3}$ Gendered histories of maritime labour have intriguingly paid more attention to stewardesses than to male stewards, who have been neglected relative to deck and stokehold crews in the overtly masculinist historiography of maritime labour. ${ }^{4}$ The compromised masculinity of service crew by contrast to the archetype of the hardy seafarer goes some way to explain this neglect. Other crew members denigrated stewards for lacking nautical skill. They were also frequently men marginalised by race or sexual orientation. ${ }^{5}$

To address the changing face of service labour at sea demands bridging seemingly distinct contexts and literatures of service employment. In flight, air hostesses began to replace stewards in the 1930s, just as waitresses were beginning to be hired in greater numbers on shore. Air hostesses have attracted significant scholarly attention, and in ways more attentive to the wider contexts of service labour. ${ }^{6}$ Shipping and aviation histories,

\footnotetext{
${ }^{3}$ Mäenpää, 'Comfort and Guidance'; Mäenpää, 'Women Below Deck: Gender and employment on British passenger liners, 1860-1938', Journal of Transport History 25, no. 2 (2004): 57-74; Lorraine Coons, 'From "Company Widow" to "New Woman": Female Seafarers Aboard the "Floating Palaces" of the Interwar Years', International Journal of Maritime History 20, no. 2 (2008): 143-174; Jo Stanley, 'Co-venturing Consumers “Travel Back”: Ships' Stewardesses and Their Female Passengers, 1919-55', Mobilities 3, no. 3 (2008): 437-454. See also Jo Stanley, From Cabin 'Boys' to Captains: 250 Years of Women at Sea (Stroud: The History Press, 2016).

${ }^{4}$ But see Sari Mäenpää, 'Galley News: Catering Personnel on British Passenger Liners, 1860-1938', International Journal of Maritime History 12, no. 1 (2000): 243-260. Leon Fink's major historical survey privileges 'ordinary seamen', and while touching on stewards, dates women's employment to the 1950s. See Sweatshops at Sea: Merchant Seamen in the World's First Globalized Industry, From 1812 to the Present (Chapel Hill: University of North Carolina Press, 2011), 175.

${ }^{5}$ Julia Martínez, Claire Lowrie, Frances Steel and Victoria Haskins, Colonialism and Male Domestic Service across the Asia Pacific (London: Bloomsbury, 2019), 137-167; Paul Baker and Jo Stanley, Hello Sailor! The Hidden History of Gay Life at Sea (London: Longman, 2003).

${ }^{6}$ For example, Kathleen M. Barry, Femininity in Flight: A History of Flight Attendants (Durham: Duke University Press, 2007); Christine Yano, Airborne Dreams: "Nisei" Stewardesses and Pan American World Airways (Durham: Duke University Press, 2011; Phil Tiemeyer, Plane Queer: Labor, Sexuality, and AIDS in the History of Male Flight Attendants (San Francisco: University of
} 
however, remain siloed, perhaps reflecting a perception that the jet swiftly superseded the passenger liner. And yet, for over four decades flight and shipping were more complementary than competitive. ${ }^{7}$ Putting women on board was central to the attitudes that aviation commanded. It also enticed people back to sea.

Women performing the same kind of work were labelled differently at different sites. Depending on the type of ship, female service crew at sea could be 'waitresses', 'stewardettes' or 'seamanettes', sometimes even 'stewards'. 'Stewardess' usually described a matronly figure who attended female passengers in their cabins. The aviation industry eschewed 'waitress' for 'stewardess' or 'hostess', and only much later adopted the genderneutral 'attendant.' Gendered labels were also sexualised in context, with the youthful flight stewardess ascribed a more desirable figure than her older counterpart at sea. Using examples predominantly from the US and Britain, I draw out the ways gender and race shaped and were shaped by shifting perceptions and practices of work in these contexts.

The article begins with a brief historical profile of gendered and racialized employment in the hospitality services, then turns to the shipboard steward. It then plots the employment of waitresses in place of stewards from two different but linked angles. The third section discusses the period before World War II when race became more crucial to employment in the American mercantile marine. The final two sections discuss a brief postwar period when shipping companies' efforts to reinvent passenger shipping to take on the challenge of commercial aviation renewed attention to the employment of women. Three

California Press, 2013); Peter Lyth, “"Think of her as your mother”: Airline advertising and the stewardess in America, 1930-1980', Journal of Transport History 30, no. 1 (2009): 155-181. ${ }^{7}$ Frances Steel, “"Time is on our side”: Shipping and the Coming of Flight', in Pacific Futures: Past and Present, eds Warwick Anderson, Miranda Johnson and Barbara Brookes (Honolulu: University of Hawai'i Press, 2018), 107-130. 
decades after gaining a foothold, waitresses at sea were frequently perceived as novel, controversial or even threatening figures, responses that can shed further light on the gendered power and status of service work.

\section{The Service Industry as a Man's Domain}

The mid-nineteenth-century growth of industry and urbanisation generated an unprecedented expansion of waged service employment in positions such as waiters, bartenders and cooks. ${ }^{8}$ Men predominated in these roles. Associated with servility, in the United States they were largely occupied by African Americans. Although such 'low status' work in restaurants and railroad dining cars, as much as in ships' saloons, 'need not have been racial', as historian W. Jeffrey Bolster remarks, whites insisted that only blacks could take up positions that they associated with 'retrograde masculinity'. ${ }^{9}$ However, rather than internalising notions of degradation, African American stewards gained regard within their communities as respectable providers, in notable contrast to the wayward and often kinless white seafarer. Railroad porters, emancipated southern black men employed by the Pullman Company from 1867, were, as their historian explains, 'a kind of aristocracy of Negro labor', with steady

\footnotetext{
${ }^{8}$ Daniel Levinson Wilk, 'The Red Cap's Gift: How tipping tempers the rational power of money', Enterprise \& Society 16, no. 1 (2015): 15.

${ }^{9}$ As addressed for example in Andrew Haley, Turning the Tables: Restaurants and the Rise of the American Middle Class, 1880-1920 (Chapel Hill: University of North Carolina Press, 2011); Eric Arnesen, Brotherhoods of Color: Black railroad workers and the struggle for equality (Harvard University Press, 2002); W. Jeffrey Bolster, Black Jacks: African American seamen in the age of sail (Cambridge, MA: Harvard University Press, 1997), 34, 167.
} 
employment and high rates of home ownership who rose to prominence in their communities. $^{10}$

Despite being regarded as feminised work, service employment in Europe and Britain became a province of white men. In upper-class and exclusive establishments, including grand hotels and fashionable restaurants, men dominated wait staff. Dictating this male monopoly was a culture of conspicuous consumption, and the gratification that leisure-class men derived from the subordination and command of other members of their own sex. ${ }^{11}$ Even in domestic settings, commanding a 'manservant' spoke to the male employer's status and masculine dominance. Waiters in public establishments protected their masculinity by cultivating an appearance of dignity and respectability. For example, they refused to be visually differentiated from those they served. This included resisting bans on moustaches and, by extension, as historian Rosalind Eyben argues, 'the effeminate masculinity of cleanshaven domestic servants'. ${ }^{12}$

In Gilded Age United States, elite dining culture outside the South shifted course to prefer western Europeans, especially those trained in France or Switzerland. The white waiter 'evok[ing] an aristocratic past where wealth commanded loyalty', also appealed to nouveau riche sensibilities. ${ }^{13}$ As late as the 1930s, despite the fact one-quarter of male waiters were

\footnotetext{
${ }^{10}$ Arnesen, Brotherhoods of Color, 24. See also Beth Tompkins Bates, Pullman Porters and the Rise of Protest Politics in Black America, 1925-1945 (Chapel Hill: University of North Carolina Press, 2001).

${ }^{11}$ Rosalind Eyben, “"The moustache makes him more of a man”: Waiters' Masculinity Struggles, 1890-1910', History Workshop Journal 87 (2019): 197, 206.

${ }^{12}$ Eyben, “"The moustache makes him more of a man”, 190.

${ }^{13}$ Haley, Turning the Tables, 34.
} 
black, white men always held the more prestigious positions, whether serving in elite establishments or holding supervisory roles such as head waiter. ${ }^{14}$

In 1900 men accounted for about two-thirds of all waiting staff, and two decades later still comprised over half. ${ }^{15}$ Indeed, women were marginalised. Americans associated waitressing with moral degradation. The figure of a woman serving single men or groups of men was unsettling, worse still if this involved alcohol. A tipping culture dictated that servers put on a friendly demeanour, but such behaviour, it was feared, might blur social and sexual boundaries, compromising waitresses. ${ }^{16}$ Such reservations also resonated across Britain and its settler colonies, but they were not universal. During a New Zealand parliamentary debate over a licensing bill in 1874 , for instance, one proponent elevated waitresses to a 'class of respectable people', who were 'certainly much more acceptable to the ladies who have to be attended to in the confectioners' rooms and cafes in "empire cities" than ... men would be.'17 Ideals of white women's civilising and domesticating influence on the colonial frontier extended here to the urban public sphere, but in ways that also recognised white women as consumers who could command appropriately gendered service.

Such settler colonial valorisations found echoes in the 'opening' of the North American West. While the railroad dining car remained the preserve of African American waiters, from the 1880s railroad companies hired women for dining rooms at rail stops along the Atchison, Topeka and Santa Fe lines. The waitresses employed in the chain of eating houses established by entrepreneur Fred Harvey famously came to be known as 'Harvey

\footnotetext{
${ }^{14}$ Dorothy Sue Cobble, Dishing it out: waitresses and their unions in the twentieth century (Urbana: University of Illinois Press, 1991), 18.

${ }^{15}$ Cobble, Dishing it out, 2-3.

${ }^{16}$ For a British colonial example, see 'A "trap for girls", Cromwell Argus, 14 September 1870, 7.

${ }^{17}$ New Zealand Times, 16 September 1874, 2.
} 
Girls'. Harvey initially employed men but replaced them with white women after disturbances at Raton, New Mexico, where black waiters received blame for poor service and night brawls. The women proved so popular he began to employ them everywhere instead of men. ${ }^{18}$ The Harvey chain changed the image of waitressing, as a respectable avenue for young women who lived and worked together under close supervision. ${ }^{19}$

More white women took up waitressing in the US, due, in part, to labour shortages following World War I, as well as to 'changing consumer tastes' fostered by 'fantasies of racial domination [giving] ... way to sexual desire', claimed historian Daniel Levenson Wilk. ${ }^{20}$ Black self-determination played a role, with African American men increasingly preferring more impersonal forms of employment in manufacturing and industry. ${ }^{21}$ As restrictions on female interaction with male strangers loosened, waitresses gained recognition for their supposed superiority, and, as historian Dorothy Sue Cobble shows, their 'greater cleanliness, tact, efficiency, and adaptability'. With employers also expecting a more sexualised disposition to please, men found themselves unable to compete. ${ }^{22}$ Yet the work itself was still held in low esteem as menial and unskilled. ${ }^{23}$

Across the Anglo world, white men continued to dominate service positions in highstatus establishments. Even as restaurants and eating houses were opening up to waitresses,

\footnotetext{
${ }^{18}$ Lesley Poling-Kempes, The Harvey Girls: Women who opened the west (New York: Paragon House, 1989), 42.

${ }^{19}$ Poling-Kempes, The Harvey Girls.

${ }^{20}$ Wilk, 'The Red Cap's Gift', 25.

${ }^{21}$ Bates, Pullman Porters and the Rise of Protest Politics, 25-26.

${ }^{22}$ Cobble, Dishing it Out, 19, 21-22.

${ }^{23}$ Cobble, Dishing it Out, 24-26, 45; Frances Donovan, The Woman Who Waits (Boston: Gorham Press, 1920), 130, 134.
} 
other venues —notably mobile labour sites like railroad dining-cars and ship saloonsremained the preserve of waiters.

\section{Steamship Stewards: Identities and Expectations}

Examining shipboard service at greater length allows for better situating waitresses who eventually found a foothold at the expense of the stewards. With the application of steam to shipping, passenger travel expanded. So did expectations of service. As ships became bigger and shipowners began to recognise the competitive advantages of good service on board, the catering department grew in size, eventually outstripping the engine and deck departments. ${ }^{24}$

Service workers at sea included kitchen and pantry staff, saloon (dining-room) stewards, as well as cabin, bathroom and deck stewards. Besides emotional labour, the prized qualities of a waiter at sea made demands unknown to waiters on shore. According to one 1932 description, '.. he has at least two languages; he has ingenuity; tact that amounts to diplomacy; the ability to take and obey orders like a soldier; a real love of the sea, even when not a good sailor; and he has to have the power to inspire confidence in times of danger' ${ }^{25}$

Women also joined the catering department as stewardesses, a specific and supplementary role. More constrained than the steward, the stewardess served only female passengers and in more intimate and select exchanges. Their employment was idealised as training young, unmarried women for domestic life (similar to tearoom waitresses, who according to the English social reformer Charles Booth worked in a 'half way house between

\footnotetext{
${ }^{24}$ A sketch of a 17,000-ton luxury liner lists 46 seamen, 51 engine-room crew and 198 stewards and other attendants, as reproduced in Illustrated London News, 21 October 1933.

25 'Good Morning, Steward!', Saturday Evening Post, 14 May 1932, 111.
} 
school and altar') ${ }^{26}$ But women were more often hired for their prior domestic experience ashore. They were usually older than male crew, frequently single or widowed, or regarded as 'odd women' left alone to support a family. ${ }^{27}$ Regardless of her age, the stewardess could struggle to overcome suspicions of being a source of disorder in crew relations and hierarchies of authority, as male crew feared the loss of the idealised ship as a common home that bound men to one another. Indicative of female isolation, Figure 1 portrays the saloon crew of a typical colonial coastal steamer, with the lone stewardess outnumbered by ten stewards and kitchen staff.

[Insert FIG 1 about here]

Growing catering and cabin crews supposedly unfamiliar with nautical traditions undercut established notions of hardy, seafaring masculinity. It was commonplace that seamen disdained stewards because they accepted tips in exchange for routine personalised service which merchant seamen might perform only 'in an emergency or as an act of charity' ${ }^{28}$ Such presumptions of docility may have reflected the seaman's lament for an idealised age of sail and his fear of becoming 'a kind of male housemaid' ${ }^{29}$

\footnotetext{
${ }^{26}$ Cited in Patricia van den Eeckhout, 'Waiters, Waitresses, and their Tips in Western Europe before World War I', International Review of Social History 60, no. 3 (2015): 345.

${ }^{27}$ Lorraine Coons and Alexander Varias, Tourist Third Cabin: Steamship Travel in the Interwar Years (New York: Palgrave, 2003), 108.

${ }^{28}$ Frank Bullen, The Men of the Merchant Service. Being the Polity of the Mercantile Marine for 'Longshore Readers (New York: Frederick A. Stokes Company, 1900), 179, 180.

${ }^{29}$ Frank Bullen, evidence, Report of the Committee Appointed by the Board of Trade to Inquire into the Mercantile Marine: II - Minutes of Evidence [Cd 1608], (1903), 618.
} 
Heterosexual stewards may in fact have been in a minority. The stewards department in one company was said to be 70 percent gay in the $1930 \mathrm{~s} .{ }^{30}$ Oral histories contend this was open knowledge. Many stewards proudly self-identified as 'queens', and called each other 'waitresses', 'stewardesses' or 'sisters', though only in their own quarters rather than on the job. ${ }^{31}$ Shipping company personnel files in the 1920s and 1930s are largely silent on stewards' sexuality, with commentary more fixated on appearance, cleanliness and temperament. Despite undercurrents of prejudice and hostility, evidence of employer discrimination is missing until the early 1960s, when companies like the British Orient Line shunned gay stewards, particularly those who flaunted their 'abnormality', as 'undesirable elements' and a demoralising influence'. ${ }^{32}$ At the same time, as historians Paul Baker and Jo Stanley have shown, others were more receptive and their ships reputed as 'havens' for gay men. Officials might also extol gay sensibilities as befitting the occupation while allaying any concerns about impropriety with female passengers. ${ }^{33}$ Conversely, routine contact with women in the course of their work further 'diluted' stewards' masculinity in the eyes of other crew. $^{34}$

As on shore, attitudes towards the respectability of service workers varied with the prestige of their workplace and the heritage and traditions they embodied. The transatlantic trades between Europe and North America were the most prestigious. The British companies

\footnotetext{
${ }^{30}$ This was the Matson Line of San Francisco. See Allan Bérubé, 'No red-baiting! No race-baiting! No queen-baiting!: The Marine Cooks \& Stewards Union from the Depression to the Cold War', Lecture presented at the first Canadian Lesbian and Gay Trade Union Conference, Ottawa, Canada, October 1997, audio recording produced by Estelle Freedman and John D'Emilio, 2016, http://outhistory.org/exhibits/show/no-baiting/red-race-queen (accessed 14 July 2019).

${ }^{31}$ Bérubé, 'No red-baiting! No race-baiting! No queen-baiting!'.

${ }^{32}$ Oriana voyage reports 1962-1963, Orient Line records, Caird Library, OSN/12/10.

${ }^{33}$ Baker and Stanley, Hello Sailor!, esp. chapter 7.

${ }^{34}$ Baker and Stanley, Hello Sailor!, 14, 41.
} 
Cunard and White Star, for example, earned reputations for exacting standards of service, founded on naval discipline and reinforced by strict codes of deference. Their service crews were generally white and British. In contrast, employers were often wary of American stewards because of their reputation for independence. This trait made an American 'quite impossible' in the role of steward, the British Nautical Magazine asserted: 'To him a steward is a waiter ashore and a waiter is a lackey to an extent which goes against his Republican spirit'. ${ }^{35}$ Such perceptions partly explain why American companies employed Chinese stewards (and Filipino men after 1898) on their Asian routes. Departing San Francisco in 1898, a British passenger recorded his preference for Chinese waiters as 'hardworking, attentive and tidy' even if 'far less communicative' than African Americans. ${ }^{36}$ African American stewards and cooks, once prominent in the age of sail, were largely displaced from the deep ocean trades and mainly restricted to US coastal routes.

In Britain's Indian Ocean trades, the employment of non-white service crews expanded with the repeal of the Navigation Acts in 1849. The premier imperial shipping firm Peninsular \& Oriental Steam Navigation Company (P\&O) employed Indian men as 'general servants' in the galley, as officers' servants, or to attend to Indian passengers. From the latenineteenth century, cheaper saloon crews from Goa on 'Asiatic' articles replaced stewards and cooks hired under European articles. ${ }^{37}$ Other British shipping lines turned to Chinese and non-white colonial male subjects, notably for itineraries to Asia and Africa. Racialised and feminised stereotypes of docility, devotion, and loyalty fostered these preferences. ${ }^{38}$

\footnotetext{
${ }^{35}$ Nautical Magazine 110, no.1 (1923): 17.

${ }^{36}$ Charles P. Trevelyan, Letters from North America and the Pacific (London, Chatto \& Windus, 1969), 117-118.

${ }^{37}$ G. Balachandran, Globalizing Labour? Indian seafarers and world shipping (Delhi: Oxford University Press, 2012), 100.

${ }^{38}$ Martínez et al, Colonialism and Male Domestic Service.
} 
The settler colonies in Australia and New Zealand fashioned their communities in the interests of white labour, targeting for exclusion prospective migrants or crews temporarily in port. Local shipping companies renounced employing non-white crew, yet American ships trading between San Francisco and Sydney depended on Chinese and occasionally African American workers. On one ship the head steward was black, reported a traveller in 1883, 'and it was curious to note how he lorded it over the white stewards', a rare instance of an inverted racial hierarchy and a racially mixed department - and a scene not witnessed again. ${ }^{39}$ After Pacific Mail withdrew in 1885, Oceanic Steam Ship Company-which also carried Chinese stewards - resisted what it regarded as unwarranted interference by Australasian maritime unions, but by the late 1880 s it had acceded to a 'white Pacific'. ${ }^{40}$ Even as white labour claimed these trades as their exclusive preserve, stewards were not falling over themselves to work them. Companies faced continued problems securing men in San Francisco as well as in Sydney. Those who turned up were seldom 'clean and fresh and tidy', complained one employer in 1913, and there was 'no saying in what condition they may return to the ship' at way ports. $^{41}$

\section{Ocean-Going Waitresses Make an Appearance}

By the early 1930s women's shipboard work expanded beyond roles supporting and protecting female passengers. Stewardesses still attended to them, but women were also employed as nurses, laundresses, nannies, hairdressers and social hostesses. Many women

\footnotetext{
${ }^{39}$ Richard Tangye, Reminiscences of Travel in Australia, America and Egypt (London: Sampson Low, 1883), 115.

${ }^{40}$ Frances Steel, 'Anglo Worlds in Transit: Connections and frictions across the Pacific', Journal of Global History 11, no. 2 (2016): 263-264.

${ }^{41}$ David Mills, Sydney to James Mills, Dunedin, 3 February 1913, Hocken Collections, Union Steam Ship Company records, AG-292-005-004/115.
} 
saw shipboard work as an opportunity for travel. They also started to be hired in positions earlier occupied by men.

The Grace Line (W.R. Grace \& Company) in the United States first replaced male dining-room 'stewards' with 'waitresses'. On a trial basis in 1929, women worked on routes between the US and South America. This program reflected the expectation that passengers preferred to be served 'by neat and personable young women rather than by masculine attendants' ${ }^{42}$ The company received numerous applications, including from 'college girls and social butterflies' who it thought put travel above the work. It moved to recruiting 'professional waitresses' through an employment agency. ${ }^{43}$ Waitresses then became a permanent fixture, expected, like stewards before them, to have 'more than an average degree of intelligence, a flare [sic?] for foreign languages, and steady "sea legs"'. Their presence helped cultivate the image of a new fleet of Grace ships launched in 1933 as 'homes-at-sea' ${ }^{44}$

This shift towards women occurred alongside a 'whitening' of the American mercantile marine demanded by the International Seamen's Union of America (ISU). The ISU represented deck and engine crews rather than stewards, but its demand for American seamen threatened the employment of all 'Asiatics', whether or not American-born, from American-flagged ships. The Seamen's Act 1915 stipulated that 75 percent of the crew on American vessels would understand commands in English. With sign language and pidgin English ruled acceptable, many Chinese continued to work on American ships. Though some lines may have managed to retain Chinese crews until the 1930s, the Merchant Marine Acts

\footnotetext{
${ }^{42}$ Honolulu Advertiser, 29 July 1929, 2.

${ }^{43}$ Pittsburgh Press, 2 July 1929, 5; Brooklyn Daily Eagle, 4 May 1930, 11.

${ }^{44}$ Council Grove Republican, 27 June 1933, 4.
} 
of 1928 and 1936 required 75 percent of crews on American vessels and 90 percent on subsidised ones to be Americans, and the rest, legal aliens entitled to American citizenship. ${ }^{45}$

The Grace Line's turn to white waitresses occurred in this context. Discontinuing its 'many Chinese stewards' meant higher wage costs. ${ }^{46}$ Hiring American waitresses in preference to waiters was hence a strategic compromise; these workers presented an acceptable white face, but cost less than their male counterparts while still embodying the 'softer', more 'agreeable' demeanour commonly associated with 'Oriental' waiters. ${ }^{47}$

In the 1930s, airlines also began employing women in preference to men as 'hostesses' or 'stewardesses'. They were not called 'waitresses' because the term was not felt to be sufficiently aspirational. Male-dominated cultures of service at sea and in upper-class establishments on shore influenced commercial aviation from the start. Here, too, the status and wealth of elite clients was best confirmed by male, rather than female, attendance. US airlines forbade tipping, and passengers belonged almost entirely to a white elite. ${ }^{48}$

The technical requirements of early flight placed responsibilities upon the steward beyond care, including 'notionally manly ground duties' like baggage handling. ${ }^{49}$ Pan American Airways, 'America's Merchant Marine of the Air', drew from the traditions of the sea more than turning its back on them. On board its flying boats, the steward was not just a

\footnotetext{
${ }^{45}$ Fink, Sweatshops at Sea, 93-115, 159-164; René De La Pedraja, The Rise and Decline of U.S. Merchant Shipping in the Twentieth Century (New York: Twayne Publishers, 1992), 22, 97-98.

${ }^{46}$ Honolulu Advertiser, 29 July 1929, 2.

${ }^{47}$ Martínez, et al, Colonialism and Male Domestic Service, 142-143, 156-167.

${ }^{48}$ Barry, Femininity in Flight, 17. On Qantas, stewards received tips but hostesses did not. See Prudence Black, The Flight Attendant's Shoe (Sydney: NewSouth Publishing, 2011), 72.

${ }^{49}$ Phil Tiemeyer, 'Technology and Gay Identity: The case of the pre-Second World War male flight attendant', History and Technology 27, no. 2 (2011), 157, 159, 160.
} 
waiter, but seaman, purser, and cook as well. A 1943 call for recruits to work the transatlantic routes set out the company's expectations:

They don't want merely 21-to-32-year-old lads who 'just love to fly' and who can wrestle a skillet. First he has to be robust. Then he has to speak at least one foreign language fluently. He must know seamanship and first aid, and be familiar with immigration and customs regulations of various countries, be ready to answer questions by curious passengers, figure foreign exchange, be responsible for international mail ....

The role also required physicality and daring: 'the Steward-to-be will learn how to use and launch life rafts, use fire extinguishers, improvise emergency safety measures, and swim' ${ }^{50}$ White men were believed to be uniquely qualified for such tasks signalling safety and reassurance. ${ }^{51}$ But the steward was also expected to be a 'kindly and willing' nanny if required, with knowledge 'in such things as how to make babies stop crying'. ${ }^{52}$

New aircraft of the 1930s provided more cosy domestic interiors and encouraged women and children passengers on board. Historian Phil Tiemeyer has shown that stewards began to be rendered as 'laughable "male hostesses"', if not 'deviant' homosexuals. ${ }^{53}$ Women also began to be employed, although not on Pan American until the 1940s (Figure 2). Air hostesses initially required nursing qualifications, but from the outset the role embodied both nurturing and desirability, attentiveness and attractiveness. Women were selected according to 'white middle-class ideals of femininity', particularly youth, beauty, slimness, and poise. ${ }^{54}$

\footnotetext{
${ }^{50}$ Wisconsin State Journal, 22 July 1943, 20.

${ }^{51}$ Barry, Femininity in Flight, 17.

${ }^{52}$ Wisconsin State Journal, 22 July 1943, 20.

${ }^{53}$ Tiemeyer, ‘Technology and Gay Identity’, 158, 156.

${ }^{54}$ Barry, Femininity in Flight, 12.
} 
Historian Kathleen Barry posits that the presence of air hostesses created 'home-like familiarity', an emphasis similar to that for waitresses on Grace Line vessels around the same time. $^{55}$

[FIG 2 about here]

Travel opportunities enticed prospective recruits to both sea and the air. But waitresses faced union opposition. In 1933 the Seamen's Journal protested that a 'large percentage' of the Grace Line waitresses were 'not interested in wages' but simply 'after free trips'. ${ }^{56}$ Yet the extent and nature of women's mobility, its cultural definitions, and its public presence began to change from the $1920 \mathrm{~s} .{ }^{57}$ The ship became a public space for fashioning modernity, and the overt commercialisation of sea travel turned into a site for feminine pleasure and leisure. New sea-going labour opportunities resonated with these shifts. Waitresses on American ships further received new significance at a time of huge state investments in the mercantile marine to break the grip of foreign vessels on American seaborne trade. ${ }^{58}$ By the late 1930 s, a number of lines advertised for waitresses, an occupation now endorsed as 'an excellent vocational outlet for women'. Successful applicants would be 'neat, deft, and attractive', over the age of thirty, and have experience in 'smart restaurants' and a good understanding of 'French menu terms'. 59

\footnotetext{
${ }^{55}$ Barry, Femininity in Flight, 23.

${ }^{56}$ Seamen's Journal XLVII, no.6 (1 June 1933): 87.

${ }^{57}$ Alisa Freedman, Laura Miller, and Christine R. Yano, 'You Go Girl! Cultural meanings of gender, mobility, and labor', in Modern Girls on the Go: Gender, Mobility and Labor in Japan, eds. Freedman, Miller and Yano (Stanford: Stanford University Press, 2013), 9. 58 'Use American Ships', Yazoo Herald, 12 April 1932, 2; De La Pedraja, Rise and Decline, 59-78. ${ }^{59}$ James C. Healy, 'Opportunities and occupations in the American merchant marine', Journal of Counseling and Development 17, no. 6 (1939): 521.
} 
Other companies were employing sea-going waitresses. Newspapers from the early 1930s carry references to waitresses on the Norwegian American Line, while in 1931 Nippon Yusen Kaisha trialled 200 'kimono-clad' waitresses on its Japan-San Francisco route who were reportedly paid the same as the 'boys' they replaced. ${ }^{60}$ In the 1930 s, women took up positions of dining-room cashiers and cooks on British cargo vessels. ${ }^{61}$ Russian and Norwegian cargo lines also permitted women to sign on as 'crewmen'. ${ }^{62}$

Work seems to have been coded by gender, and where women may not necessarily have performed a decorative presence in addition to their functional roles, the gender coding of work appeared to trump the gender identity of workers. On cargo lines, where passengers were few and women tended to other (male) crew, they were called 'steward' not 'waitress'. During World War II, members of the British Admiralty's Women's Royal Naval Service (WRENS) who served men at naval bases, including on training ships (Figure 3), were also rated as stewards. This practice continued after the war. Women employed on cargo ships in the 1950s, including former WRENS, refused to be called 'stewardesses' because they did not serve female passengers. ${ }^{63}$ Gender codes might be deployed rather absurdly in other contexts, however. One account designated the nine female stewards sent by the National Maritime Union in 1943, and whom the McCormick Company of New York refused to accept, as 'seamanettes'. While illustrating continuing opposition, this incident also suggests that the women themselves did not consider such employment to be out of the ordinary. Sent

\footnotetext{
${ }^{60}$ Brooklyn Daily Eagle, 13 December 1931, 81; The Capital Journal, 12 March 1931, 17.

${ }^{61}$ Stanley, From Cabin 'Boys' to Captains, 216.

${ }^{62}$ Sydney Morning Herald, 7 December 1937, 4; Santa Maria Times, 8 March 1943, 6.

${ }^{63}$ Lansing State Journal, 29 November 1948, 20; 'Women at Sea', Sea Breezes 5 (1948): 230;

Courier Mail, 6 September 1951, 3; Melbourne Argus, 24 April 1952, 32. Thanks to Jo Stanley for sharing these sources.
} 
as a test case with the approval of the War Shipping Administration, McCormick's refusal left them puzzled by the company's 'anti women' stand. ${ }^{64}$

[FIG 3 about here]

During the war naval officials deemed female crew out of place on passenger ships converted to troop carriers. After the war, it was not uncommon for (male) stewards to resent the return of stewardesses on grounds that they had coped perfectly well without them. ${ }^{65}$ This inversion of postwar expectations of women who filled 'men's' jobs during the war illustrates the extent to which some forms of female service employment on ships had become normalised by this time.

\section{Postwar Service and the Remaking of Sea Travel}

World War II saw rapid advances in aviation. Meanwhile, wartime privations tarnished the image of sea travel. Afterwards, shipping companies had to entice people back to the 'slow ocean' in preference to or in combination with flight. ${ }^{66}$ Some companies took to the air to expand traffic. Others intentionally bypassed it. As the British Union Castle Line told its shareholders, 'we feel the sea is our medium and that we should confine our attention to that' ${ }^{67}$ Wary of positioning sea travel as 'little more than the transport of passengers',

\footnotetext{
${ }^{64}$ Santa Maria Times, 8 March 1943, 6; The Times (Hammond, Indiana), 8 March 1943, 14; San Bernardino County Sun, 11 March 1943, 1.

${ }^{65}$ Coons, 'From “Company Widow" to "New Woman", 159. Matson resisted reappointing stewardesses in its trades to Hawai 'i, Bérubé, 'No red-baiting! No race-baiting! No queen-baiting!'. ${ }^{66}$ Steel, “"Time is on our side"”, 118-124.

${ }^{67}$ The Times [London] 28 May 1954, 11.
} 
shipping companies strove to transform it into an experience. ${ }^{68}$ Matson's new tagline attempted to capture this strategic shift: 'Sail Matson .... the voyage is a vacation - the ports are a plus'. ${ }^{69}$

1959 market research reported that 'the "travel mind"" still remained 'open' to the sea. 'We ... think that everyone now flies, but the fact is that $70 \%$ of the American public still [have] not taken to the air'. ${ }^{70}$ Nevertheless, as the fear of flight receded, the larger US airlines began to promote their global reach and glamourized their service. Pan American recruited Hispanic stewardesses from 1950 for its Latin American routes and, more ostentatiously, 'Nisei', or second-generation Japanese-American, women from Hawai' $i$, in 1955 for flights to Japan and its round-the-world network. According to historian Christine Yano, these attendants symbolised Pan American's success in domesticating 'otherness' in support of 'the global politics of post-war America'. ${ }^{71}$ Valued for their perceived 'subservience' and loyalty, traits long associated with Asian ship stewards, this substitution was not a modern departure as much as a refashioning of western colonialist tropes. In flight, 'Nisei' recalled being treated like exotic 'dolls', racialised by white passengers in ways not experienced growing up in Hawai ${ }^{1} .^{72}$

After the war, some shipping companies began to recruit male crews trained to provide refined service. ${ }^{73}$ Others, including Matson in the Pacific and Union Castle between

\footnotetext{
${ }^{68}$ The Times Supplement on RMS Transvaal Castle, 18 January 1962, vi.

${ }^{69}$ Reproduced in Duncan O’Brien, The White Ships: 1927-1978 (Victoria BC: Pier 10 Media, 2008), 93.

${ }^{70}$ Proposal Matson Line Passenger Traffic Advertising, Fuller \& Smith \& Ross, 1959, San Francisco National Maritime Historical Park Library, Matson Line Papers, Box 16, HDC457, original emphasis.

${ }^{71}$ Yano, Airborne Dreams, 19.

${ }^{72}$ Yano, Airborne Dreams, 100-101.

73 'Ship Stewards Go to School', Oakland Tribune, 24 November 1947, 15.
} 
Southampton and Durban, turned to waitresses in preference to stewards. After a long postwar lull, Matson revived its passenger trade to Australia in 1956 in hopes of dispelling the 'myth' of a 'dying' merchant marine. ${ }^{74}$ Though new ships reproduced exotic colonial images of Polynesia in their interiors, Matson did not hire Pacific Islanders as waitresses, who were more likely to be from Europe and Australia, as well as the United States, including from Cherokee Indian reservations. The Marine Cooks and Stewards Union (MCSU) appointed the women who rated as merchant mariners. Matson looked to women ostensibly in response to the shortage of first-class stewards on the US west coast. Even so, it continued to hire men, who held all senior positions, including head waiter. Of the $275 \mathrm{crew}$ on each vessel, 16 percent were women: in addition to 30 waitresses, there was a hostess, a secretary to the Chief Steward, two stewardesses, a 'yeomanette' (petty officer), three switchboard operators, one librarian and, while not rated as crew, two nurses, two beauticians, and one gift shop attendant. $^{75}$

Unlike airlines, which forced female crew to retire by age 32 or 35, Matson employed older waitresses, who were mostly in their 30 s or 40 s; the eldest was 53 . Some had teenagers to support, while three, though still in their 40s, were grandmothers who 'wanted to see the world'. ${ }^{76}$ These waitresses thus resembled the matronly figure of the pre-war steamship stewardess. Like stewardesses, waitresses were expected to be relatively unobtrusive on board. They were assigned separate quarters and enclosed deck areas. Not permitted to mingle with crew or passengers, they were described as 'ship phantoms' who disappeared to a 'no man's land' after each dining service. Passengers, the 1960 report lamented, 'get

\footnotetext{
${ }^{74}$ Randolph Sevier, 'New ships for a new era,' n.d., 'Mariposa 3' folder, Matson Corporate Archive, Oakland (hereafter MCA).

${ }^{75}$ Morning Call [Allentown, Pennsylvania], 13 January 1963, 10.

${ }^{76}$ Honolulu Advertiser 2 November 1956, 9.
} 
nowhere trying to date them'. ${ }^{77}$ To an observer at a New Zealand port, 'these ladies' did not appear to be 'the very young heady type of girl, but handpicked waitresses, chosen for their cleanliness, tactfulness, experience and general outlook on life' ${ }^{78}$ None of this stopped male shipping officials expecting waitresses to cultivate an attractive amenability. An Australian assistant to the head waiter, dismissed after one voyage, was denounced as 'an unattractive female' who did little but 'moan about the horrible workload that she carries.' 'The room needs an attractive sophisticated woman' instead. ${ }^{79}$

Emulating American precedents, in 1962 Union Castle turned to waitresses for its new one-class 'hotel' ship, the Transvaal Castle. They were designated as 'stewardettes'. This odd coinage probably acknowledged the negative associations of waitressing. Indeed, with the coming of mass air travel, air hostesses, too, would complain that they were no longer 'hostesses' but only 'glorified' or 'airborne' waitresses. ${ }^{80}$ Still, Transvaal Castle's first complement of 40 stewardettes, selected from over one thousand applicants, all had at least four years waitressing experience. Standards were 'not quite as rigorous' as on airlines and the new recruits included a few married women, though here women with children were not employed. $^{81}$

Waitressing at sea was comparatively lucrative. During Matson's 42-day round-trip voyage from San Francisco (with stops at Hawai 'i, Tahiti, Samoa, Fiji, New Zealand and Australia), women earned about $\$ 450$ a month plus tips (with a base pay of $\$ 405$, not counting overtime), and enjoyed free lodgings, meals, and uniforms. This compensation far

\footnotetext{
${ }^{77}$ Unknown press clipping, 1 October 1960, File Mariposa II, Vancouver Maritime Museum.

${ }^{78}$ The Log: World Ship Society, Australia and New Zealand 4, no. 1 (March 1957).

7912 November 1956, Mariposa III folder, MCA.

${ }^{80}$ Barry, Femininity in Flight, 110-111.

${ }^{81}$ The Times Supplement on RMS Transvaal Castle, 18 January 1962, v.
} 
exceeded wages on shore, as well as of their counterparts in the air who might earn between \$255 and \$355 a month and who, as convention dictated, could not be tipped. Outside of the medical and legal professions, Matson's waitresses were 'possibly ... the highest income group among women in the United States', with their monthly wage, including free board, estimated at almost $\$ 700 .{ }^{82}$ In contrast to the air, with hostesses ostensibly trained as homemakers in waiting, the gendered domesticity on ships appears to have been more ambiguous. The job relieved women of domestic chores, now performed by other (male) crew. Some passengers considered the living and working conditions of waitresses so 'wonderful' that they resented having to tip them. ${ }^{83}$

Though relatively invisible in voyage promotional materials, waitresses at sea were a press drawcard, with reports and interviews emphasising their broadening horizons and freedoms, at times exemplified by disposable income. 'I own pearls and jade I would never have bought if I stayed in Denver', as 44 year-old divorcee, Myrna Sechler remarked. ${ }^{84}$ In the 1960s, others referred to waitresses as 'expert shoppers', much sought after by passengers for advice on bargains at ports. ${ }^{85}$ While perhaps trivialising waitresses as workers, such reports also highlight their satisfaction at leading independent lives. ${ }^{86}$ If in 1957 Australia 'the girls now are regarded as true celebrities', ${ }^{87}$ other waitresses soon tired of the publicity that followed them around the world. ${ }^{88}$

\footnotetext{
${ }^{82}$ Santa Maria Times, 7 December 1956, 4.

83 'Passenger comments', Marisposa III folder, MCA.

${ }^{84}$ Morning Call (Allentown, Pennsylvania), 13 January 1963, 10.

${ }^{85}$ San Antonio Express, 9 July 1967, 78.

${ }^{86}$ Barry, Femininity in Flight, 207-208.

${ }^{87}$ Honolulu Advertiser, 3 March 1957, 99.

${ }^{88}$ Such as those on the British freighter Langleeclyde, see Durban Mercury, 6 December 1955. Thanks to Jo Stanley for sharing this source.
} 


\section{Feminisation and Unionisation}

Scorned as 'unseamanly', stewards were capable of turning the tables on waitresses. In 1956 the MCSU-denounced in the late 1930s as 'one third red, one-third black and one-third queer $^{89}$ — resorted to traditional nautical conflations of women and danger at sea to stoke fears for the safety of the Mariposa sailing the Pacific, far from land and going 'days without sighting other ships'. A 'special edition' of the MCSU newsletter invoked the spectre of waitresses breaking into panic when their ship ran into trouble, and 'physically incapable women' attempting to rescue male passengers or rowing lifeboats clear of a foundering ship. Such scaremongering had been commonplace for several decades with respect to Asian crews. ${ }^{90}$ Published just a day before Mariposa's maiden voyage, the newsletter gave immediacy to these fears by linking them to the recent sinking of the transatlantic passenger liner Andrea Doria off the Nantucket coast. While 46 people lost their lives in the accident, the 'experienced and physically able crewmen' had saved more than 1,600 others. ${ }^{91}$ The newsletter acknowledged that passenger ships had always known female crew in the figure of the 'indispensable stewardess'. However, they were a tiny minority who learned the trade 'one by one and became good "seamen"', in contrast to the 'so many women newcomers' hired for the Mariposa.

The MCSU's concern for the 'morale of the crewmen' occurred against the backdrop of ongoing rivalry between two unions, the International Longshoremen's and Warehousemen's Union (ILWU) and the Seafarers' International Union (SIU). In 1955 the SIU won the right to represent stewards on ships of the Pacific Maritime Association. This

\footnotetext{
${ }^{89}$ Bérubé, 'No red-baiting! No race-baiting! No queen-baiting!'

${ }^{90}$ Balachandran, Globalizing Labour?, 49, 111.

91 “Another "Andrea Doria"”?, Stewards News 1, no. 38 (23 October 1956), enclosed in Examiner clippings, San Francisco Public Library (hereafter SFPL). Original emphasis.
} 
development dealt a severe blow to the MCSU, which was part of the ILWU. ${ }^{92}$ Attacking the SIU leader Harry Lundeberg as the 'no.1 gangster of the Pacific', the newsletter accused him of seeking to 'increase his power' by replacing 'hundreds of bonafide seamen' with 'novice women' that 'he can control'. From this perspective, waitresses were favoured because they were regarded as less militant or more pliant than men. ${ }^{93}$

For their part, Matson's chief stewards enthused that waitresses were more congenial, neater in their work, and took greater interest in such 'important little things' as keeping flower arrangements alive 'about three days longer than men do, by their tender care'. ${ }^{94}$ Passengers, too, liked their presence, which they regarded as 'a step in the right direction.' Waitresses fast became 'sentimental favorites'. ${ }^{95}$ The only complaints following the maiden voyage to Australia were, perhaps predictably enough in retrospect, about the 'tea-room' look of the women's uniforms. ${ }^{96}$ (Figure 4 ).

[FIG 4 about here]

\footnotetext{
92 Jane Cassels Record, 'The rise and fall of a maritime union', Industrial and Labor Relations Review 10, no.1 (1956): 81-92. See also Gerry Jamin, 'Marine Cooks and Stewards Union: historical essay', http://www.foundsf.org/index.php?title=Marine_Cooks_and_Stewards_Union (accessed 1 April 2019).

93 "Another "Andrea Doria"'? Thanks to Charlotte Macdonald for raising this question of labour militancy.

${ }^{94}$ File 'Mariposa II', Vancouver Maritime Museum.

${ }^{95}$ Passenger comments, Mariposa III folder, MCA.

${ }^{96} 12$ November 1956, Mariposa III folder, MCA. They were later re-designed by Nadine Bergen, who also styled airline stewardesses, San Antonio Express, 9 July 1967, 78.
} 
Parallel tendencies may be seen in Britain, where the National Union of Seamen (NUS) supported the employment of stewardettes on the Transvaal Castle. ${ }^{97}$ A dissident section known as the Seamen's Reform Movement (SRM) denounced women's employment, which the organisation linked to the NUS's acceptance of the merged P\&O-Orient Line recruiting Goan saloon crews. Threatening to 'tie up' the port if 'one more Goanese or ... Stewardette' was employed, the SRM raised the spectre of women 'infiltrating' other ship departments. What might happen 'when they introduce[d] Deckettes and Donkey Greaserettes', its newsletter exclaimed.$^{98}$ Here the steward—long denigrated as lacking nautical traditions and skill—morphed into the shared identity of 'seamen'.

There were limits to the interchangeability of men and women at sea, or what one newspaper would later describe as 'industrial transvestism'. ${ }^{99}$ Matson briefly reverted to waiters in the San Francisco-Honolulu trades in 1963. Given a shortage of qualified women, it could not mix crews because of their sex-segregated quarters. In protest 'a 90 -pound waitress in ballerina shoes' held up the ship for six hours demanding that women be rehired. Longshoreman refused to cross her picket line. ${ }^{100}$ A 1968 Title VII case further tested the limits of 'industrial transvestism' when the National Maritime Union (NMU) sent Grace Line five men to fill the vacancies for 'waitresses' because they met the job qualification and had been longest out of work. The NMU also sent women to replace waiters on two other lines. All three companies rejected the workers and asserted their right to maintain crews' quarters separated on board by sex. Reportedly the first union dispute relating to sex-based job

\footnotetext{
${ }^{97}$ Stanley, From Cabin 'Boys' to Captains, 217. Former stewardette, Sha Wylie, recalled no hostility, as they were regarded not as replacements but 'decorative' additions to the male crew (personal communication 14 April 2019).

${ }^{98}$ Balachandran, Globalizing Labour?, 41.

${ }^{99}$ Daily News, 5 October 1968, 14.

${ }^{100}$ El Paso Herald, 29 March 1963, 11; San Francisco Examiner, 29 March 1963, 14.
} 
discrimination under Title VII, the labour arbitrator 'added to the lore of the sea' by upholding the companies' right to refuse to hire men and women 'at random'. If women were to be treated the same as men at work, they should perhaps be treated the same 'when their work is through'. However, waiters and waitresses could not be required to sleep in the same quarters, hence anti-sex discrimination laws 'stopped at the bedroom door'. ${ }^{101}$

\section{Conclusion}

The entry of women into a sphere of feminised work long monopolised by men raises questions about the shifting relationship between gender, service, and status. With respect to US passenger shipping, women's entry into ships' dining rooms occurred over a thirty-year period, first with the Grace Line and, later, Matson. Though British ships employed women in various service roles since the mid-nineteenth century, waitresses first worked on cargo liners in the 1930s. Only one major player (Union Castle) finally hired them for passenger vessels in the 1960s. Three international passenger lines hardly marked a universal shift. Even on lines employing waitresses, men continued to be hired for deck and cabin positions and filled all senior service roles. They remained arguably 'grander'. ${ }^{102}$ Yet to view these developments in a wider context, as mass commercial travel sought to recreate some aspects of domestic comfort as more people began to undertake volitional long-distance journeys, women's service became normalising, reassuring, and enticing.

Race was never far in the background. Growing state interest in dictating entitlements to maritime employment led to the Grace Line recruiting women in the place of Chinese stewards. Racialisation also shaped the replacement of white men by white women on

\footnotetext{
${ }^{101}$ Courier-Journal, 5 October 1968, 11; Baltimore Sun, 3 October 1968, 34.

${ }^{102}$ Eyben, “"The moustache makes him more of a man”, 197.
} 
Matson and Union Castle ships. Waitresses and Asian crews shared stereotypes of an admired demeanour, their 'weakness' in times of crisis, and the threat they posed to white men's jobs. In these debates, the once-troubling figures of the stewardess and the steward were recuperated as more 'at home' at sea than the waitress ever could by virtue of their longer assimilation to shipboard traditions.

Steward, stewardess, stewardette, waitress, and hostess might often designate the same work. On the other hand, stewardess had different connotations on a plane than at sea, and waitressing came with added glamour on ships than ashore, including travel, consumption, and though not addressed in this article, identification with national ambitions and projects. Moreover, men might self-feminise as waitresses, while women might insist on continuity by being rated as stewards. Identities might be fluid and interchangeable, but spaces could still limit the blurring of gender boundaries. Discrimination might persist because ships doubled as both workplace and temporary home. Ships remained a place apart also for conflating different contexts for and of domesticity. Yet recognising this requires situating the ship in relation to other sites of service employment on land, a longer history at sea, as well as in the air. 